\title{
International Students Assesment of Service Quality In Academic Libraries
}

\author{
Baffour Gyau Emmanuel, Jing Liu \\ Institute of Science and Technology Information, Jiangsu University, China
}

\begin{abstract}
Service quality assessment is a key and significant issue in library management since it gives criticism to libraries to enhance on services delivery to their users. This study presents LibQUAL $+{ }^{\mathrm{TM}}$ tool and SERVQUAL gap analysis by measuring the perception and expectation of the quality services provided by academic libraries from the point of view and experiences of international students in Jiangsu University. The 22-item LibQUAL $+{ }^{\mathrm{TM}}$ instrument, measuring the three service dimensions of Affect of Service, Information Control and Library as Place, was administered to the international students, with 201 respondents based on simple random sampling. The researchers used analysis method like descriptive statistics, reliability analysis and exploratory factor analysis. The study revealed that international students who are users of the Jiangsu University Library have high expectations of service quality at Jiangsu University Library whiles perception of services delivered by Jiangsu University Library was a mixture of both low and high across the three dimension of service quality based on the LibQUAL+ ${ }^{\text {TM }}$ instrument. In addition, the results show that there is negative gap for Affect of Serve (-0.62) and Information Control (-0.54) dimension and a positive gap for Library as Place (0.07) service dimension. Even though, the library has high perception for one of the dimensions, the overall level of service quality (-0.44) is low and negative. This study therefore fills in as a guide for various libraries to utilize while leading service quality appraisal for their users and furthermore makes recommendation for libraries to consider in the provision of services for their users particularly international students.
\end{abstract}

Keywords: Service quality, LibQUAL $+{ }^{\mathrm{TM}}$, library services, international students, expectation, perception, users

\section{INTRODUCTION}

$\mathrm{L}$ ibraries in higher education institutions as a service organization play a significant role when it comes to research as well as growth and dispersion of knowledge. Academic libraries are key centers that play a huge role in supporting learning, research and several other study missions whiles being effective and efficient is their main challenge (Lane, Anderson, Ponce, \& Natesan, 2012). Therefore, academic libraries have to efficiently and effectively provide quality services to attain the expectations of their users. Thus, the library environment, it's information and communication technology services, human resources, collection of materials and the library as a place should be of better quality to attract more users, both locals and internationals to visit and make use of the library frequently.

In view of this, academic libraries are therefore urged to frequently assess the quality of services they provide in order to be at the high end of supporting learning and research works as well the needs and expectations of their users in the changing information era. Thus, frequent service quality assessment based on users' experiences of the various library services will assist the library to improve, evolve and innovate in its service provision to meet the needs and expectations of all their user. Previously, the volume and diversity of books and journals, size and the number of users were the ways in which the quality of libraries were assessed and measured. Nevertheless, to better ascertain and evaluate quality of library services, users are included in the evaluation process in order for the library to obtain acceptable and valid results (Zabed Ahmed \& Hossain Shoeb, 2009). Nejati and Nejati (2008) outlined service quality in relation to library studies as the difference between the desires of library users and experiences of service performance. Relying on this definition, quality of service in relation to library refers to the fact that, the behavior and satisfaction of academic library users being it good or bad, emanate from the type of services they receive from these academic libraries. Therefore, assessing library service quality from the user's perspective is the best way for academic libraries to know their level of service quality delivery.

An academic library is accessible to all students and professionals in education, regardless of age, program of study or professional status, level of study, country and other groups. Thus, academic libraries provide services to distinct and diverse group of users and should thereby make sure the services they provide meet the expectations of these diverse user groups from their level of study, program of study, to their nationality in service delivery to achieve a greater level of user satisfaction and be highly user centered. In this rapid changing education environment, academic libraries need to be internationally innovative in resources and services to provide quality services and resources for teaching and research to meet the expectations of their international users.

Globally, the number of students who take an interest in formal or tertiary education outside their own nation continues expanding year after year and is expected to continue increasing rapidly in the following decade. This clearly appeared in the steady growth of international students coming to study in China lately. With a sharp increment in the quantity of foreign students coming to study in China, it is significant for academic libraries to be updated internationally to address and meet the desires of all users particularly the 
international students. Jiangsu University is not exempted from this consistent increment in foreign students who come to study in China.

According to the Overseas Education Center (OEC), the university has about 2000 international students from 80 unique nations enrolled in bachelor, masters, doctorate and post-doctoral programs. Dominant parts of these countries are African and Asians (Non-Chinese) and these students originate from different nations all over the world with unique and widely backgrounds such as, religion, socio-economic, tradition, political structure and language. It is important to cognize that, international students are a motley group. The university library ought to accordingly know about and understand the needs and desires of international students in so as to enhance and improve their services to fulfill the international users' needs.

In China and numerous nations, higher educational institutions like college and university have its primary academic library that provides high quality and effective information services and resources for educating and research at the school. These high-quality services are intended to address and attain the desires of all users such as locals and international users of that academic library. The Jiangsu University Library (JUL) comprises of the Main Library, the Mengxi Campus Library, the Beigu Campus Library, the Jingjiang College Section and four reference rooms located in social science, arts administration and foreign languages. Jiangsu University Library offers a clear manner of organized services including the collection and circulation of books, talent education, in addition to research information and consultations, which has been and will continue to provide services, effective information and quality resources for teaching and research at Jiangsu University.

A library is said to keep up an elevated level of service quality when it is able to provide its user with the required and needed information and materials at the right and required state. In this manner, fulfilling the necessities and requests of every single user of the library is what is implied by quality library service (Sahu, 2007). Notwithstanding, the primary aim of this study is to assess the quality of service of the Jiangsu University Library based on international students' expectations and perceptions.

\section{LITERATURE REVIEW}

Service quality is a major factor to be considered and to be practiced by the service industry because customers fulfillment relies upon the nature of the services they get from these organizations. In such manner, service quality has gotten generous proportion of affirmation, from numerous establishments including libraries and also academic scholars in various field of study including library and information sciences. Academic libraries ought to comprehend that service quality is of high incentive to service organizations since it aids in developmental decisions associated with its users' needs and satisfaction. The quality of service can be alluded to as the perceived judgment, which the customer secures when he contrasts his service desires with the services he really encounters and understands (Wong \& Sohal, 2003). In light of this definition, library users' needs and desires are exceptionally critical to decide the quality services rendered in academic libraries.

Service quality should assume a significant role in academic libraries since these libraries have diverse classification of users from various background, race, culture and language. Academic libraries ought to in this manner offer quality and better services to the entire academic community thinking about every single user of the library. Likewise, they should response to change in accordance with all of its users' needs to fully enhance and offer quality services. This study therefore seeks to measure whether international students who are part of the users of academic libraries have all their needs and desires being met.

As indicated by Grönroos (2001) study referred to in Wong and Sohal (2003), service quality is relied on these two variables, perceived and expected services. The services that clients or customers truly get from an organization and the services connected with the clients' past experience or general impression of the service respectively. At the point when service expectancy is higher or lower than service perception, service quality is considered low or high, respectively. Therefore, so as to accomplish higher service quality in academic libraries, services provided ought to be of high value and as indicated by users' needs and desires. Since academic library users comprise of various heterogenous group of users, the library needs to consider every single user so as to know their needs and attain a higher level of service quality. This study therefore assesses the level of quality of services rendered by academic libraries to all users specifically the international students based on both the LibQUAL+ ${ }^{\mathrm{TM}}$ and SERVQUAL survey tools.

Unlike products quality, service quality is not easy to assess for customers, since the concept of quality is subjective according to Ananthanarayanan Parasuraman, Berry, and Zeithaml, (2002) cited in Mosadeghrad (2013). With regards to needs and wants, customer satisfaction may differ from one person to another since the perception and assessment of quality by customers also differ (Venetis \& Ghauri, 2004). Most studies that assessed service quality focused on customers' expectations and service perceptions. Therefore, quality of services rendered in academic libraries is a continuous process whereby all users regardless of your race, discipline, culture and language are the main determinants.

According to Pritchard, (1996) it is important to supervise and satisfy the needs of users of academic libraries in relation to quality management. Services quality provision by libraries are assessed primarily through performance measures such as input and turnout measures (Hernon \& Altman, 1996). These performance measures will regularly assist academic libraries to acquire information regarding their activities and to provide 
better and quality services to all its users rendered them to vindicate their relevance to the library management. However, Hebert, (1994) acknowledges that, achieving internal management set standards does not connote a better performance by the library according to its users. In this regard, users of academic libraries should be the main determinants of the quality of services rendered by the library and their performance. This is affirmed by Tan and Foo, (1999), a library survival depends to a large extent on the benefits to users. The existence of libraries will be compromised and its services will be demeaned when users start looking for different options to library services. They added that another way for libraries to show value is continually provide quality service all users.

Although there are many models for evaluating the service quality, the SERVQUAL model by Parasuraman, Zeithaml, and Berry, (1988) has received wide and adequate recognition from many researchers from different fields of study and it's a widely tested instrument for measuring service quality in many fields of study. According to them, the SERVQUAL instrument is a manifold item scale that consists of 22 statements which evaluates the gap between customers' expectations and perceptions established on five dimensions: Tangible, Responsiveness, Assurance, Empathy and Reliability. Many researchers have adapted the SERVQUAL instrument to assess service quality in the library sciences discipline ranging from public, special and university libraries (Tan \& Foo, 1999; Zabed Ahmed \& Hossain Shoeb, 2009; Zakaria et al., 2011). This makes the SERVQUAL instrument to be highly recognized and effective in measuring service quality in this particular field of study. This study therefore adapted its gap analysis where users' expectations and perceptions are subtracted in every item to attain a service gap.

Moreover, LibQUAL+ ${ }^{\mathrm{TM}}$ tool, a web-based service quality survey instrument is on the other hand the most widely used service quality instrument by the Association of Research Libraries (ARL) for research and university libraries across the globe. The web-based instrument was adapted from SERVQUAL and the original gap theory with 22 items survey assessing library users minimum service levels, desired service levels, and perceived performance based on three dimensions: Affect of Service, Information Control, and Library as Place and one of its major aims is to help libraries better understand user perceptions of library service quality ((Blixrud, 2012; Cook \& Heath, 2000).

About 1300 distinct libraries have participated in LibQUAL $+{ }^{\mathrm{TM}}$ since the year 2000 and these libraries are made of college and university libraries, community college libraries, health sciences libraries, academic law libraries, and public libraries, others through various consortia, others as independent participants. In 2017, 3,085 institutional surveys were conducted in 1,383 institutions in 34 countries, with 19 language translations and more than 2.8 million respondents. About $37 \%$ of users who responded to the survey provide rich feedback on how they use their libraries. LibQUAL+ ${ }^{\mathrm{TM}}{ }_{\mathrm{S}}$ growing community of participants and a comprehensive data set are rich resources for improving library services (ARL, 2018). This makes LibQUAL+ ${ }^{\mathrm{TM}}$ instrument the best tool for assessing the quality of services provided by libraries and the study adapts it because of its authenticity, reliability and consistency.

According to Heath, (2003), A. Parasuraman in 2003 said at a training session on SERVQUAL and LibQUAL+ ${ }^{\mathrm{TM}}$ at the January 2003 American Library Association Midwinter Meeting in Philadelphia, "LibQUAL $+{ }^{\mathrm{TM}}$ is not just a survey. It is a tool to advance internal change based on information." While the widespread use of such a protocol may in itself be a shift in the assessment culture within libraries, it is also important to note that LibQUAL+ ${ }^{\mathrm{TM}}$ scores in a wide range of institutions are fairly psychometrically and reasonable in its settings.

A study at the Library Faculty of Communication Padjadjaran University by Asep Saeful Rohman, (2016) revealed the need for libraries to do a better programme in order to achieve the desires of its users by improving the quality of its services. Their study employed the LibQUAL $+{ }^{\mathrm{TM}}$ instrument to assess service quality and its effect on users' satisfaction (Rohman, 2016). Our study therefore tries to identify the basic service quality dimensions, desires and experiences of international users of academic libraries.

In another study M Masoom Raza and Abdus Samim, (2016) adapted the LibQUAL $+{ }^{\mathrm{TM}}$ instrument in measuring the quality of services in Maulana Azad Library where 100 library users completed questionnaire to determine users expectations and satisfaction (Raza \& Samim, 2017). Our study also adopts the LibQUAL $+{ }^{\mathrm{TM}} 22$ survey items to assess the international users' expectations and perceptions of quality of services rendered in academic libraries.

\section{METHODOLOGY}

In assessing the quality of service in academic libraries from international students' point of view, this study used questionnaire-based survey method which was conducted at Jiangsu University Library. Therefore, to better evaluate and gain understanding of service quality in an academic library, this study seeks to examine international students' expectations and perceptions of library services rendered by the Jiangsu University Library. Jiangsu University has international student about population of two thousand students as at March 2019 and these international students are from eighty different countries with majority of students from Africa and Asia (Non-Chinese) countries as indicated by information from the overseas education college. Utilizing a simple random sampling, 201 international students participated in this study.

For this study, Cook, Heath, and Thompson, (2002) LibQUAL $+{ }^{\mathrm{TM}}$ model was adapted to gather data to examine the quality of service of the library of Jiangsu University. The instrument was administered to postgraduate international 
students enrolled in the library department to test the instrument for face validity and few items were modified. To also test for consistency and reliability of the items and dimensions used in the questionnaire, a reliability test was conducted. The Cronbach's alpha value of the expectation variables was 0.949 . whiles the Cronbach's alpha values of 0.902 is for the perception scale. This implies that the three dimensions items are statistically reliable and dependable.

The survey constructed expected respondents to evaluate international users' desires and observations dependent on the LibQUAL $+{ }^{\mathrm{TM}} 22$ core items and furthermore some qualitative information given by these international users' as open-ended remarks. These remarks in spite of the fact that not $100 \%$, brings out international users' service quality perceptions, and make specific recommendations for service quality enhancement for these specific users.

To measure and quantify the desires and observations of international users', five Likert scale was utilized with " 1 " being "Strongly Disagree" and " 5 " being "Strongly Agree" to gauge respondents' consent to the item presented. Other sections of the survey contain demographic questions. Data from the responses was dissected using the SERVQUAL gap theory where expectations scores were subtracted from perception scores for each item in three service dimensions by $\mathrm{LibQUAL}^{+\mathrm{TM}}$ tool to obtain the gap score, also referred to as superiority mean. Thus, mean values for all the items are calculated for both expected and perception services. Furthermore, means scores for the expected services is subtracted from perception means to attain the service mean gap scores/ superiority gap. The data was analyzed using Statistical Package for the Social Science (SPSS) version 25 in getting data and information. By this SPSS, the researchers utilized analysis methods like descriptive statistics and reliability testing.

\section{RESULTS}

The findings of the present study are based purely on the response returned by the users. A total of 201 students participated in the survey and based on the data collected, the Kaiser-Meyer-Olkin measure of Sampling Adequacy is 0.904 meaning the sample is adequate.

\section{Demography of respondents}

In this study, the researchers discuss the respondents' demographic background such as gender, age, country, academic level and academic discipline. With reference to Table 1, representing a categorization of survey respondents by gender, $71.1 \%$ of the respondents are male and $28.9 \%$ are female. The number and percentage for each gender are given for the survey respondents.
Table 1: Gender of Respondents

\begin{tabular}{|c|c|c|}
\hline Gender & $\begin{array}{c}\text { Respondents } \\
\mathbf{n}\end{array}$ & $\begin{array}{c}\text { Respondents } \\
\text { \% }\end{array}$ \\
\hline Male & 143 & 71.1 \\
\hline Female & 58 & 28.9 \\
\hline Total & $\mathbf{2 0 1}$ & $\mathbf{1 0 0}$ \\
\hline
\end{tabular}

Note: $\mathrm{n}$ and \% represent the number of respondents for each question and the percentage of the respondents respectively. Authors compilation.

Also, table 2 shows a classification of survey respondents by age; both the number of respondents (n) and the percentage of the total number of respondents represented by each age group are displayed. The majority of the respondents were aged between 21 and 30 years representing $65.7 \%$ and minority of them are aged over 40 years which represents $1 \%$.

Table 2: Age of Respondents

\begin{tabular}{|l|l|l|}
\hline Age & $\begin{array}{l}\text { Respondents } \\
\mathbf{n}\end{array}$ & $\begin{array}{l}\text { Respondents } \\
\%\end{array}$ \\
\hline Under 20 & 10 & 5.0 \\
\hline $21-30$ & 132 & 65.7 \\
\hline $31-40$ & 57 & 28.4 \\
\hline Over 41 & 2 & 1.0 \\
\hline Total & $\mathbf{2 0 1}$ & $\mathbf{1 0 0}$ \\
\hline
\end{tabular}

Note: $\mathrm{n}$ and $\%$ represent the number of respondents for each question and the percentage of the respondents respectively. Authors compilation.

According to table 3, showing a dissection of survey respondents by their country, $54.7 \%$ of the respondents are from Africa, $40.3 \%$ are from Asia (Non-Chinese), $4.5 \%$ are Europeans and $0.5 \%$ from America. This confirms an enquiry conducted about international students from the overseas education office that, Africans and Asia (Non-Chinese) students were highly populated in the school.

Table 3: Continent of Respondents

\begin{tabular}{|c|c|c|}
\hline Continent & $\begin{array}{c}\text { Respondents } \\
\mathbf{n}\end{array}$ & $\begin{array}{c}\text { Respondents } \\
\text { \% }\end{array}$ \\
\hline Africans & 110 & 54.7 \\
\hline Asians (Non-Chinese) & 81 & 40.3 \\
\hline Europeans & 9 & 4.5 \\
\hline Americans & 1 & .5 \\
\hline Total & $\mathbf{2 0 1}$ & $\mathbf{1 0 0}$ \\
\hline
\end{tabular}

Note: $\mathrm{n}$ and \% represent the number of respondents for each question and the percentage of the respondents respectively. Authors compilation.

Furthermore, table 4 shows survey respondents' details in terms of their academic level. Majority of the respondents are master students representing $55.7 \%$ followed by undergraduate, $27.9 \%$ and post-doctoral student represented by others has the minority respondents representing $1.0 \%$ 
Table 4: Academic Level of Respondents

\begin{tabular}{|c|c|c|}
\hline Academic Level & $\begin{array}{c}\text { Respondents } \\
\mathbf{n}\end{array}$ & $\begin{array}{c}\text { Respondents } \\
\mathbf{\%}\end{array}$ \\
\hline Undergraduate & 56 & 27.9 \\
\hline Master & 112 & 55.7 \\
\hline Doctorate $(\mathrm{PhD})$ & 31 & 15.4 \\
\hline Other & 2 & 1.0 \\
\hline Total & $\mathbf{2 0 1}$ & $\mathbf{1 0 0}$ \\
\hline
\end{tabular}

Note: $\mathrm{n}$ and $\%$ represent the number of respondents for each question and the percentage of the respondents respectively. Authors compilation.

Lastly table 5 below shows survey respondents in terms of their academic discipline, based on their responses to the demographic background questions. Majority of the respondents were from the Business Management and Economics and Engineering/Computer Sciences disciplines and the percentages are $39.3 \%$ and $30.3 \%$ respectively.

Table 5: Academic Discipline of Respondents

\begin{tabular}{|c|c|c|}
\hline Academic Discipline & $\begin{array}{c}\text { Respondents } \\
\mathbf{n}\end{array}$ & $\begin{array}{c}\text { Respondents } \\
\mathbf{\%}\end{array}$ \\
\hline Science/Math & 16 & 8.0 \\
\hline $\begin{array}{c}\text { Engineering/Computer } \\
\text { Sciences }\end{array}$ & 61 & 30.3 \\
\hline $\begin{array}{c}\text { Business Management and } \\
\text { Economics }\end{array}$ & 79 & 39.3 \\
\hline Arts and Social Sciences & 22 & 10.9 \\
\hline Health Sciences & 18 & 9.0 \\
\hline Education & 3 & 1.5 \\
\hline Other. Please specify & 2 & 1.0 \\
\hline Total & $\mathbf{2 0 1}$ & $\mathbf{1 0 0}$ \\
\hline
\end{tabular}

Note: $\mathrm{n}$ and $\%$ represent the number of respondents for each question and the percentage of the respondents respectively. Authors compilation.

\section{International students' expectation and perception of library} service quality

\section{Service quality expectations}

The result from table 6 shows that respondents prioritize the following service items: 'Readiness to respond to users' questions' (4.49), 'Employees who understand the needs of their users' (4.46), 'Modern equipment that lets me easily access needed information' (4.4), 'Easy-to-use tools that allow me to find things on my own' (4.35), 'Willingness and readiness to help users' (4.29) and 'A library Web site enabling me to locate information on my own (user friendly library website)' (4.27). The overall expectation service was 4.21. 'Information Control' has the highest mean score of 4.22, followed by the 'Affect of service' mean score is 4.20 and 'Library as Place' mean score of 4.19.

\section{Perceived quality service level}

As academic library has the central character of providing quality service to its users, their services are supposed to meet the needs of all their users including international students.
Highest perceived service provided by the library from international users perspective are as follows: 'A comfortable and inviting location' (4.32), 'Community space for group learning and group study' (4.29), 'Library space that inspires study and learning' (4.25), 'A getaway for study, learning, or research' (4.23) and 'Quiet space for individual activities' (4.2). The overall perceived service was 3.77. 'Library as Place' has the highest mean score of 4.26, 'Information Control' has a mean score of 3.68, and 'Affect of service' mean score of 3.58.

Table 6: Mean scores of international students' service expectations and perceptions and mean gap score (superiority mean) $\mathrm{N}=201$

\begin{tabular}{|c|c|c|c|}
\hline Questions & $\begin{array}{l}\text { Expected } \\
\text { Service } \\
\end{array}$ & $\begin{array}{l}\text { Perceived } \\
\text { Service } \\
\end{array}$ & $\mathbf{n}$ \\
\hline \multicolumn{4}{|l|}{ Affect of Service } \\
\hline $\begin{array}{l}\text { Employees who instill } \\
\text { confidence in users }\end{array}$ & 4.23 & 3.25 & 201 \\
\hline $\begin{array}{l}\text { Giving individual } \\
\text { users the attention, } \\
\text { they need }\end{array}$ & 4.17 & 3.67 & 201 \\
\hline $\begin{array}{l}\text { Employees who are } \\
\text { consistently courteous }\end{array}$ & 4.08 & 3.86 & 201 \\
\hline $\begin{array}{l}\text { Readiness to respond } \\
\text { to users' questions }\end{array}$ & 4.49 & 3.6 & 201 \\
\hline $\begin{array}{l}\text { Employees who have } \\
\text { the knowledge to } \\
\text { answer user questions }\end{array}$ & 4.04 & 3.14 & 201 \\
\hline $\begin{array}{l}\text { Employees who deal } \\
\text { with users in a caring } \\
\text { fashion }\end{array}$ & 4.02 & 3.76 & 201 \\
\hline $\begin{array}{l}\text { Employees who } \\
\text { understand the needs } \\
\text { of their users }\end{array}$ & 4.46 & 3.55 & 201 \\
\hline $\begin{array}{l}\text { Willingness and } \\
\text { readiness to help users }\end{array}$ & 4.29 & 3.76 & 201 \\
\hline $\begin{array}{l}\text { Dependability in } \\
\text { handling users' service } \\
\text { problems }\end{array}$ & 4.1 & 3.67 & 201 \\
\hline \multicolumn{4}{|l|}{ Information Control } \\
\hline $\begin{array}{l}\text { Making electronic } \\
\text { resources accessible } \\
\text { from my home or } \\
\text { office }\end{array}$ & 4.19 & 3.66 & 201 \\
\hline $\begin{array}{l}\text { A library Web site } \\
\text { enabling me to locate } \\
\text { information on my } \\
\text { own (user friendly } \\
\text { library website) }\end{array}$ & 4.27 & 3.79 & 201 \\
\hline $\begin{array}{l}\text { The printed library } \\
\text { materials I need }\end{array}$ & 4.02 & 3.73 & 201 \\
\hline $\begin{array}{l}\text { The electronic } \\
\text { resources I need }\end{array}$ & 4.16 & 3.81 & 201 \\
\hline $\begin{array}{l}\text { Modern equipment } \\
\text { that lets me easily } \\
\text { access needed } \\
\text { information } \\
\end{array}$ & 4.4 & 3.93 & 201 \\
\hline $\begin{array}{l}\text { Easy-to-use tools that } \\
\text { allow me to find things } \\
\text { on my own }\end{array}$ & 4.35 & 2.87 & 201 \\
\hline $\begin{array}{l}\text { Making information } \\
\text { easily accessible for } \\
\text { independent use }\end{array}$ & 4.19 & 3.77 & 201 \\
\hline $\begin{array}{l}\text { Print and/or electronic } \\
\text { journal collections I } \\
\text { require for my work }\end{array}$ & 4.25 & 3.92 & 201 \\
\hline
\end{tabular}




\begin{tabular}{|l|l|l|l|}
\hline \multicolumn{2}{|l|}{ Library as Place } & 4.25 & 201 \\
\hline $\begin{array}{l}\text { Library space that } \\
\text { inspires study and } \\
\text { learning }\end{array}$ & 4.18 & 4.2 & 201 \\
\hline $\begin{array}{l}\text { Quiet space for } \\
\text { individual activities }\end{array}$ & 4.17 & 4.32 & 201 \\
\hline $\begin{array}{l}\text { A comfortable and } \\
\text { inviting location }\end{array}$ & 4.2 & 4.23 & 201 \\
\hline $\begin{array}{l}\text { A getaway for study, } \\
\text { learning, or research }\end{array}$ & 4.17 & 4.29 & 201 \\
\hline $\begin{array}{l}\text { Community space for } \\
\text { group learning and } \\
\text { group study }\end{array}$ & 4.24 & $\mathbf{3 . 7 7}$ & $\mathbf{2 0 1}$ \\
\hline Overall & $\mathbf{4 . 2 1}$ & & \\
\hline
\end{tabular}

Note: $\mathrm{N}=201$ indicates the total number of respondent whiles ' $n$ ' represents the number of respondents for each question.

\section{Gap score and service quality level}

The findings from tables 7 and 8 revealed that there are mix of both negative and positive scores in the service gap scores. There is a negative service gap for 'Affect of Service' together with 'Information Control' and a positive service gap score for 'Library as Place'. Thus, international users of Jiangsu University Library ranked 'Affect of service' and 'Information Control' with a negative gap score of (-0.62) and $(-0.54)$ respectively and 'Library as Place' with a positive gap score of (0.07). The overall service quality looking at the gap score also has a negative score (-0.44) as depicted in table 9 .

The largest negative gap in all 'information control' dimension is 'Easy-to-use tools that allow me to find things on my own' $(-1.48)$ which indicates that Jiangsu University Library is far from meeting its international users' desired expectations. For the dimension of 'Affect of service' the lowest scores observed was 'Employees who instill confidence in users' (-0.98) 'Employees who understand the needs of their users' $(-0.91)$ and 'Employees who have the knowledge to answer user questions' (-0.9). For the dimension 'Information Control' lowest score was observed 'Easy-to-use access tools that allow me to find things on my own' (-1.48) and 'Making electronic resources accessible from my home or office' (-0.53). The lowest score for 'library as place' dimension was observed for the attributes of 'Quiet space for individual activities' (0.03) 'A gateway for study, learning, or research' (0.06). So, it was found that Jiangsu University Library is below satisfactory in the "Affect of Service and Information Control". The result shows the need for an immediate attention in those items having negative and wide gap scores. Ranking of gap differences between desired expectations and actual service perceptions of international students based on gap size was also assessed as shown in table 8. It depicts the performance of the library from good to worse across the three dimensions base on the gap scores.
Table 7: Mean scores of international students' service expectations and perceptions and mean gap score (superiority mean) $\mathrm{N}=201$

\begin{tabular}{|c|c|c|c|c|}
\hline Questions & $\begin{array}{l}\text { Expecte } \\
\text { d } \\
\text { Service } \\
\end{array}$ & $\begin{array}{l}\text { Perceived } \\
\text { Service }\end{array}$ & $\begin{array}{l}\text { Mean } \\
\text { Gap Score }\end{array}$ & $\mathbf{n}$ \\
\hline \multicolumn{5}{|l|}{ Affect of Service } \\
\hline $\begin{array}{l}\text { Employees who } \\
\text { instill confidence in } \\
\text { users }\end{array}$ & 4.23 & 3.25 & -0.98 & 201 \\
\hline $\begin{array}{l}\text { Giving individual } \\
\text { users the attention, } \\
\text { they need }\end{array}$ & 4.17 & 3.67 & -0.5 & 201 \\
\hline $\begin{array}{l}\text { Employees who are } \\
\text { consistently } \\
\text { courteous }\end{array}$ & 4.08 & 3.86 & -0.22 & 201 \\
\hline $\begin{array}{l}\text { Readiness to } \\
\text { respond to users' } \\
\text { questions }\end{array}$ & 4.49 & 3.6 & -0.89 & 201 \\
\hline $\begin{array}{l}\text { Employees who } \\
\text { have the knowledge } \\
\text { to answer user } \\
\text { questions }\end{array}$ & 4.04 & 3.14 & -0.9 & 201 \\
\hline $\begin{array}{l}\text { Employees who } \\
\text { deal with users in a } \\
\text { caring fashion }\end{array}$ & 4.02 & 3.76 & -0.26 & 201 \\
\hline $\begin{array}{l}\text { Employees who } \\
\text { understand the } \\
\text { needs of their users }\end{array}$ & 4.46 & 3.55 & -0.91 & 201 \\
\hline $\begin{array}{l}\text { Willingness and } \\
\text { readiness to help } \\
\text { users }\end{array}$ & 4.29 & 3.76 & -0.53 & 201 \\
\hline $\begin{array}{l}\text { Dependability in } \\
\text { handling users' } \\
\text { service problems }\end{array}$ & 4.1 & 3.67 & -0.43 & 201 \\
\hline \multicolumn{5}{|l|}{ Information Control } \\
\hline $\begin{array}{l}\text { Making electronic } \\
\text { resources accessible } \\
\text { from my home or } \\
\text { office }\end{array}$ & 4.19 & 3.66 & -0.53 & 201 \\
\hline $\begin{array}{l}\text { A library Web site } \\
\text { enabling me to } \\
\text { locate information } \\
\text { on my own (user } \\
\text { friendly library } \\
\text { website) }\end{array}$ & 4.27 & 3.79 & -0.48 & 201 \\
\hline $\begin{array}{l}\text { The printed library } \\
\text { materials I need }\end{array}$ & 4.02 & 3.73 & -0.29 & 201 \\
\hline $\begin{array}{l}\text { The electronic } \\
\text { resources I need }\end{array}$ & 4.16 & 3.81 & -0.35 & 201 \\
\hline $\begin{array}{l}\text { Modern equipment } \\
\text { that lets me easily } \\
\text { access needed } \\
\text { information }\end{array}$ & 4.4 & 3.93 & -0.47 & 201 \\
\hline $\begin{array}{l}\text { Easy-to-use tools } \\
\text { that allow me to } \\
\text { find things on my } \\
\text { own }\end{array}$ & 4.35 & 2.87 & -1.48 & 201 \\
\hline $\begin{array}{l}\text { Making information } \\
\text { easily accessible for } \\
\text { independent use }\end{array}$ & 4.19 & 3.77 & -0.42 & 201 \\
\hline $\begin{array}{l}\text { Print and/or } \\
\text { electronic journal } \\
\text { collections I require } \\
\text { for my work }\end{array}$ & 4.25 & 3.92 & -0.33 & 201 \\
\hline \multicolumn{5}{|l|}{ Library as Place } \\
\hline $\begin{array}{l}\text { Library space that } \\
\text { inspires study and }\end{array}$ & 4.18 & 4.25 & 0.07 & 201 \\
\hline
\end{tabular}




\begin{tabular}{|l|l|l|l|l|}
\hline learning & & & & \\
\hline $\begin{array}{l}\text { Quiet space for } \\
\text { individual activities }\end{array}$ & 4.17 & 4.2 & 0.03 & 201 \\
\hline $\begin{array}{l}\text { A comfortable and } \\
\text { inviting location }\end{array}$ & 4.2 & 4.32 & 0.12 & 201 \\
\hline $\begin{array}{l}\text { A getaway for } \\
\text { study, learning, or } \\
\text { research }\end{array}$ & 4.17 & 4.23 & 0.06 & 201 \\
\hline $\begin{array}{l}\text { Community space } \\
\text { for group learning } \\
\text { and group study }\end{array}$ & 4.24 & 4.29 & 0.05 & 201 \\
\hline Overall & $\mathbf{4 . 2 1}$ & $\mathbf{3 . 7 7}$ & $\mathbf{- 0 . 4 4}$ & $\mathbf{2 0 1}$ \\
\hline
\end{tabular}

Note: $\mathrm{N}=201$ indicates the total number of respondent whiles ' $\mathrm{n}$ ' represents the number of respondents for each question.

Table 8: Ranking of gap differences between desired expectations and actual service perceptions of international students based on gap size

\begin{tabular}{|c|c|c|c|}
\hline $\begin{array}{l}\text { Rank } \\
\text { by } \\
\text { Gap } \\
\text { Size }\end{array}$ & Dimension & Statement & Gap Score \\
\hline 1 & $\begin{array}{l}\text { Library as } \\
\text { Place }\end{array}$ & $\begin{array}{l}\text { A comfortable and inviting } \\
\text { location }\end{array}$ & 0.12 \\
\hline 2 & $\begin{array}{l}\text { Library as } \\
\text { Place }\end{array}$ & $\begin{array}{l}\text { Library space that inspires } \\
\text { study and learning }\end{array}$ & 0.07 \\
\hline 3 & $\begin{array}{l}\text { Library as } \\
\text { Place }\end{array}$ & $\begin{array}{l}\text { A getaway for study, } \\
\text { learning, or research }\end{array}$ & 0.06 \\
\hline 4 & $\begin{array}{l}\text { Library as } \\
\text { Place }\end{array}$ & $\begin{array}{l}\text { Community space for group } \\
\text { learning and group study }\end{array}$ & 0.05 \\
\hline 5 & $\begin{array}{l}\text { Library as } \\
\text { Place }\end{array}$ & $\begin{array}{l}\text { Quiet space for individual } \\
\text { activities }\end{array}$ & 0.03 \\
\hline 6 & $\begin{array}{l}\text { Affect of } \\
\text { Service }\end{array}$ & $\begin{array}{l}\text { Employees who are } \\
\text { consistently courteous }\end{array}$ & -0.22 \\
\hline 7 & $\begin{array}{l}\text { Affect of } \\
\text { Service }\end{array}$ & $\begin{array}{l}\text { Employees who deal with } \\
\text { users in a caring fashion }\end{array}$ & -0.26 \\
\hline 8 & $\begin{array}{l}\text { Information } \\
\text { Control }\end{array}$ & $\begin{array}{l}\text { The printed library materials } \\
\text { I need }\end{array}$ & -0.29 \\
\hline 9 & $\begin{array}{l}\text { Information } \\
\text { Control }\end{array}$ & $\begin{array}{l}\text { Print and/or electronic } \\
\text { journal collections I require } \\
\text { for my work }\end{array}$ & -0.33 \\
\hline 10 & $\begin{array}{l}\text { Information } \\
\text { Control }\end{array}$ & $\begin{array}{l}\text { The electronic resources I } \\
\text { need }\end{array}$ & -0.35 \\
\hline 11 & $\begin{array}{l}\text { Information } \\
\text { Control }\end{array}$ & $\begin{array}{l}\text { Making information easily } \\
\text { accessible for independent } \\
\text { use }\end{array}$ & -0.42 \\
\hline 12 & $\begin{array}{l}\text { Affect of } \\
\text { Service }\end{array}$ & $\begin{array}{l}\text { Dependability in handling } \\
\text { users' service problems }\end{array}$ & -0.43 \\
\hline 13 & $\begin{array}{l}\text { Information } \\
\text { Control }\end{array}$ & $\begin{array}{l}\text { Modern equipment that lets } \\
\text { me easily access needed } \\
\text { information }\end{array}$ & -0.47 \\
\hline 14 & $\begin{array}{l}\text { Information } \\
\text { Control }\end{array}$ & $\begin{array}{l}\text { A library Web site enabling } \\
\text { me to locate information on } \\
\text { my own (user friendly } \\
\text { library website) }\end{array}$ & -0.48 \\
\hline 15 & $\begin{array}{l}\text { Affect of } \\
\text { Service }\end{array}$ & $\begin{array}{l}\text { Giving individual users the } \\
\text { attention, they need }\end{array}$ & -0.5 \\
\hline 16 & $\begin{array}{l}\text { Information } \\
\text { Control }\end{array}$ & $\begin{array}{l}\text { Making electronic resources } \\
\text { accessible from my home or } \\
\text { office }\end{array}$ & -0.53 \\
\hline 17 & $\begin{array}{l}\text { Affect of } \\
\text { Service }\end{array}$ & $\begin{array}{l}\text { Willingness and readiness to } \\
\text { help users }\end{array}$ & -0.53 \\
\hline 18 & $\begin{array}{l}\text { Affect of } \\
\text { Service }\end{array}$ & $\begin{array}{l}\text { Readiness to respond to } \\
\text { users' questions }\end{array}$ & -0.89 \\
\hline 19 & $\begin{array}{l}\text { Affect of } \\
\text { Service }\end{array}$ & $\begin{array}{l}\text { Employees who have the } \\
\text { knowledge to answer user } \\
\text { questions }\end{array}$ & -0.9 \\
\hline
\end{tabular}

\begin{tabular}{|l|l|l|l|}
\hline $\mathbf{2 0}$ & $\begin{array}{l}\text { Affect of } \\
\text { Service }\end{array}$ & $\begin{array}{l}\text { Employees who understand } \\
\text { the needs of their users }\end{array}$ & $\mathbf{- 0 . 9 1}$ \\
\hline $\mathbf{2 1}$ & $\begin{array}{l}\text { Affect of } \\
\text { Service }\end{array}$ & $\begin{array}{l}\text { Employees who instill } \\
\text { confidence in users }\end{array}$ & $\mathbf{- 0 . 9 8}$ \\
\hline $\mathbf{2 2}$ & $\begin{array}{l}\text { Information } \\
\text { Control }\end{array}$ & $\begin{array}{l}\text { Easy-to-use tools that allow } \\
\text { me to find things on my own }\end{array}$ & $\mathbf{- 1 . 4 8}$ \\
\hline
\end{tabular}

Table 9: Mean scores for each dimension of service quality

\begin{tabular}{|l|l|l|l|l|}
\hline Dimensions & $\begin{array}{l}\text { Expected } \\
\text { Service }\end{array}$ & $\begin{array}{l}\text { Perceived } \\
\text { Service }\end{array}$ & $\begin{array}{l}\text { Gap } \\
\text { Score }\end{array}$ & $\mathbf{n}$ \\
\hline $\begin{array}{l}\text { Affect of } \\
\text { Service }\end{array}$ & 4.20 & 3.58 & -0.62 & 201 \\
\hline $\begin{array}{l}\text { Information } \\
\text { Control }\end{array}$ & 4.22 & 3.68 & -0.54 & 201 \\
\hline $\begin{array}{l}\text { Library as } \\
\text { Place }\end{array}$ & 4.19 & 4.26 & 0.07 & 201 \\
\hline Overall & $\mathbf{4 . 2 1}$ & $\mathbf{3 . 7 7}$ & $\mathbf{- 0 . 4 4}$ & $\mathbf{2 0 1}$ \\
\hline
\end{tabular}

\section{DISCUSSION OF RESULTS}

Service quality assessment is a key and significant issue in library management since it gives criticism to libraries to enhance services delivery to their users. The purpose of every library is to provide and improve the services information requirements of their users. Increasing the level of users' satisfaction, and improving the level of efficiency and effectiveness for the sake of scientific advancement of the users are some of the objectives of academic libraries. This paper therefore sought to determine international students' evaluation of service quality in academic libraries based on the international user experience at Jiangsu University Library

The study revealed that international students who uses Jiangsu University Library have high expectations about the quality of services the library renders. All the services across the three dimensions of service quality, Affect of Service (4.20), Information Control (4.22) and Library as Place (4.19) have high levels of expectation scores and also with a high overall expectation score (4.21). These high expected services include, "Readiness to respond to users' questions, Employees who understand the needs of their users, Modern equipment that lets me easily access needed information, Easy-to-use tools that allow me to find things on my own, Willingness and readiness to help users, A library Web site enabling me to locate information on my own (user friendly library website), Print and/or electronic journal collections I require for my work, Community space for group learning and group study, Employees who instill confidence in users, and A comfortable and inviting location". In addition, the results show that international students have mix of high and low but positive levels of service perception as compared to their service expectations. The high service perceptions are evidence in only one dimension of service quality, thus, Library as Place (4.26). Whereas the low service perceptions can be seen in the other two dimensions of service quality, thus, Affect of Service (3.58) and Information Control (3.68) and had a low overall perception score (3.77) as compared to their service expectations. The high attributes users commonly experienced 
include "Giving individual users the attention they need, Employees who are consistently courteous, Willingness and readiness to help users, A library Web site enabling me to locate information on my own (user friendly library website), Modern equipment that lets me easily access needed information, Library space that inspires study and learning, Quiet space for individual activities, A comfortable and inviting location, A getaway for study, learning, or research, Community space for group learning and group study". The low service attributes include "Employees who have the knowledge to answer user questions, Employees who understand the needs of their users and Easy-to-use tools that allow me to find things on my own.

This study confirms a study by Rehman and Practice, (2012) investigating understanding the expectations of Pakistani Libraries users using the LibQUAL tool where concluded that Pakistani library users expected very high level of service quality. The findings on perceptions also conforms to previous study conducted by Rasli, Shekarchizadeh, and Iqbal, (2012) on perception of service quality in higher Education: perspective of Iranian students of Malaysian universities. They therefore concluded that postgraduate students from Iran in five top ranked Malaysian universities have low perceptions of education service quality in their universities, as their expectations were not met in the performance of education services. Lastly, previous study by Nzivo and Chuanfu, (2013) international students' perception of library services and information resources in Chinese academic libraries validates the findings of this current study the international students have low perceptions of quality of library services as compared to their expectations.

The study revealed that the level of service quality in the Jiangsu University Library is low and negative (-0.44). Furthermore, the library performed well in certain services though its overall service quality was low. Thus, the library had a good score in services relating to Library as Place (0.07) including Library space that inspires study and learning, Quiet space for individual activities, A comfortable and inviting location, A getaway for study, learning, or research and Community space for group learning and group study. Also, the library performed low with low scores in services relating to Affect of Service (-0.54) and Information Control (-0.62) dimensions of service quality including Giving individual users the attention, they need, Employees who have the knowledge to answer user questions, Willingness and readiness to help users, Easy-to-use tools that allow me to find things on my own and Print and/or electronic journal collections I require for my work. The results showed there is the need for an immediate attention in those services having negative and wide gap scores.

The findings of this study are contrary to the study by Kitana and Saydam, (2014) about testing the service quality provided by the university of Girne American Library. The results from their research made it obvious that service quality in Girne American University Library meets the students' perceptions and expectations. Furthermore, the findings of this study validate previous assessment and reports by the Association of Research Libraries (ARL) using the LibQUAL $+{ }^{\mathrm{TM}}$ survey tool to assess service quality in Brigham Young University : LDS Business College, Florida State University, McGill University Library and University of Oregon (ARL, 2018). Also, this current study affirms previous studies on library service quality in academic libraries using both the LibQUAL+ ${ }^{\mathrm{TM}}$ and the SERVQUAL survey questionnaires (Abu, 2004; Altman \& Hernon, 1998; Atkinson, 2016; Blixrud, 2012; Hanaysha, Abdullah, \& Warokka, 2011; Rasli et al., 2012)

The results of this study show that most of the respondents are generally satisfied with library support for their learning and also most of the them are satisfied with the way in which they are treated at the library. The study revealed that more than half $132(67 \%)$, of the respondents either strongly agree and agree that they are satisfied with the library support for their learning, research and teaching needs. Moreover, the results show that half $143(71 \%)$, of the respondents either strongly agree and agree that they are satisfied with the way in which they are treated at the library.

\section{CONCLUSIONS AND RECOMMENDATIONS}

The demographic analysis discovered that majority of the respondents in this research are male students, majority of the respondents are Africans and Asians (Non-Chinese) and more postgraduate students (master and doctorate). The Cronbach's alpha values generated for each item, both the expectations and perceptions of the reliability analysis indicates that the LibQUAL $+{ }^{\mathrm{TM}}$ tool is efficient as a measure of library service quality.

This study was able to reveal that international students from Jiangsu University have both positive and negative service quality gap about some library services in the university but an overall negative perception on service quality, as their expectations were not met in the performance of library services. The library is doing well in the dimension "Library as Place" since it has positive mean gap scores and performs badly in the 'Affect of Service' and 'Information Control' dimensions.

The critical gap for information control dimension occurs in the item "easy-to-use tools that assist me to locate things on my own" with a value of (-1.48). It is hypothesized that the wide service gap is as a result of the fact that these tools and equipment are mostly in Chinese language making it difficult for international users to operate.

The results of this study show that though Jiangsu University Library is doing fine in providing quality services to its users, it still should improve when it comes to providing some services to its international users. The results of this study are a really smart guide for the workers of academic libraries to develop projects and programs to assist and improves services to fulfill users' service expectations particularly the international students to be precise. 
In view of the research findings, it is recommended that the library administration should employ regular assessments of the library in order to listen to the voices of users, especially the international students. This will help the library to unquestionably understand the expectations and needs of these heterogenous users.

To investigate the problems users encountered when involved in library services and make recommendations, the respondents were given an open-ended space to give any further comments and recommendations about the University Library services and their comments are in summarized.

Improving on the communication and language barrier in the library in terms of the staff, books and other resources, expanding the library online accessibility and increasing library services, resources, space, orientation and attention to make the library more user friendly to the international users. The international users who partook in this examination assisted with making suggestions reasonable for international students and henceforth these recommendations will help the University library to enhance its services in relations to the international users. These suggestions made are imperative to Jiangsu University library as well as fill in as a reason for giving quality library services to international students in a diversified range of libraries across the globe.

\section{REFERENCES}

[1] Abu, N. K. (2004). Service quality dimensions: A study on various sizes of grocery retailers-A conceptual paper. Proceeding of IBBC, 633-642.

[2] Altman, E., \& Hernon, P. (1998). Service quality and customer satisfaction do matter. American Libraries, 29(7), 53-54.

[3] ARL, A. o. R. L.-. (2018). LibQUAL+® 2018 Survey Results ARL. Retrieved from http://www.libqual.org/repository. Retrieved April 2019, from Association of Research Libraries http://www.libqual.org/repository

[4] Atkinson, J. (2016). Quality and the academic library: Reviewing, assessing and enhancing service provision: Chandos Publishing.

[5] Blixrud, J. (2012). Evaluating library service quality: use of LibQUAL+TM.

[6] Cook, C., \& Heath, F. (2000). The Association of Research Libraries LibQUAL+ Project: An update. ARL Newsletter, 12-14.

[7] Cook, C., Heath, F., \& Thompson, B. (2002). LibQUAL+ One instrument in the new measures toolbox. Journal of library administration, 35(4), 41-46.

[8] Grönroos, C. (2001). The perceived service quality concept-a mistake? Managing Service Quality: An International Journal, 11(3), 150-152.

[9] Hanaysha, J. R., Abdullah, H. H., \& Warokka, A. (2011). Service quality and students' satisfaction at higher learning institutions: The competing dimensions of Malaysian universities' competitiveness. The Journal of Southeast Asian Research, 2011, $1-10$.

[10] Heath, C. C. F., \& Thompson, B. (2003). LibQUAL+TM from the $U K$ Perspective. Paper presented at the Fifth Northumbria International Conference on Performance Measurement in Libraries, Collingwood College, Durham, Great Britain.

[11] Hebert, F. (1994). Service quality: an unobtrusive investigation of interlibrary loan in large public libraries in Canada. Library \& Information Science Research, 16(1), 3-21.

[12] Hernon, P., \& Altman, E. (1996). Service quality in academic libraries: Greenwood Publishing Group.
[13] Kitana, A., \& Saydam, S. (2014). Testing the service quality provided by the University of Girne American Library. International Journal of Business and Social Science, 5(8).

[14] Lane, F. C., Anderson, B., Ponce, H. F., \& Natesan, P. (2012). Factorial invariance of LibQUAL+ ${ }^{\circledR}$ as a measure of library service quality over time. Library \& Information Science Research, 34(1), 22-30.

[15] Mosadeghrad, A. M. (2013). Healthcare service quality: towards a broad definition. International journal of health care quality assurance.

[16] Nejati, M., \& Nejati, M. (2008). Service quality at University of Tehran central library. Library Management, 29(6/7), 571-582.

[17] Nzivo, C. N., \& Chuanfu, C. (2013). International students' perception of library services and information resources in Chinese academic libraries. The Journal of Academic Librarianship, 39(2), 129-137.

[18] Parasuraman, A., Berry, L., \& Zeithaml, V. (2002). Refinement and reassessment of the SERVQUAL scale. Journal of retailing, 67(4), 114-139.

[19] Parasuraman, A., Zeithaml, V. A., \& Berry, L. L. (1988). Servqual: A multiple-item scale for measuring consumer perc. Journal of retailing, 64(1), 12.

[20] Pritchard, S. M. (1996). Determining quality in academic libraries.

[21] Rasli, A., Shekarchizadeh, A., \& Iqbal, M. J. J. I. J. o. A. R. i. M. (2012). Perception of service quality in higher education: Perspective of Iranian students in Malaysian universities. 1(1).

[22] Raza, M. M., \& Samim, A. (2017). Measuring the Quality of Services in Maulana Azad Library, AMU, Aligarh: A Study.

[23] Rehman, S. U. J. L. P., \& Practice. (2012). Understanding the Expectations of Pakistani Libraries Users:: A LibQUAL Study. Library Philosophy and Practice, 1.

[24] Rohman, A. S. (2016). Pengaruh Kualitas Layanan Terhadap Kepuasan Pengguna di Perpustakaan Fakultas Ilmu Komunikasi. $6(2)$.

[25] Sahu, A. K. (2007). Measuring service quality in an academic library: an Indian case study. Library Review, 56(3), 234-243.

[26] Tan, P. L., \& Foo, S. (1999). Service quality assessment: a case study of a Singapore statutory board library. Singapore Journal of Library \& Information Management, 28, 1-23.

[27] Venetis, K. A., \& Ghauri, P. N. (2004). Service quality and customer retention: building long-term relationships. European Journal of marketing, 38(11/12), 1577-1598.

[28] Wong, A., \& Sohal, A. (2003). Service quality and customer loyalty perspectives on two levels of retail relationships. Journal of services marketing, 17(5), 495-513.

[29] Zabed Ahmed, S., \& Hossain Shoeb, Z. (2009). Measuring service quality of a public university library in Bangladesh using SERVQUAL. Performance Measurement and Metrics, 10(1), 1732.

[30] Zakaria, Z., Hussin, Z. H., Noordin, N., Sawal, M. Z. H. M., bin Syed Ahmad, S. M. A., Zakaria, A., \& Zakaria, Z. (2011). Service Quality Dimensions In Public Library: Nothern Area Experienced. Journal of social sciences, 7(2), 265. 